\title{
Deep structural setting of the North American-Caribbean plate boundary in eastern Guatemala
}

\author{
E. Lodolo ${ }^{*}$, M. Menichetti ${ }^{2}$, M. Guzmán-Speziale ${ }^{3}$, G. Giunta ${ }^{4}$ and C. Zanolla ${ }^{1}$ \\ ${ }^{\prime}$ Istituto Nazionale di Oceanografia e di Geofisica Sperimentale, Trieste, Italy \\ ${ }^{2}$ Istituto di Scienze della Terra, Università di Urbino, Italy \\ ${ }^{3}$ Centro de Geociencias, Universidad Nacional Autónoma de México, Campus Juriquilla, Querétaro, Mexico \\ ${ }^{4}$ Dipartimento di Geologia, Università di Palermo, Italy
}

Received: June 26, 2008; accepted: February 13, 2009

\begin{abstract}
Resumen
Se presenta un modelo bidimensional de gravedad para determinar la estructura en profundidad del sistema de fallas lateral-izquierda de Motagua-Polochic, que son parte del límite de las placas América del Norte y del Caribe. Estos elementos tectónicos, sismicamente activos, atraviesan oeste-este la región de Guatemala y se sobreponen a una línea de sutura donde afloran cuerpos ophiolíticos. En las principales zonas de desplazamiento de las fallas se han desarrollado cuencas de pull-apart y regiones de restricción (push-up). El análisis estructural de algunas de estas fallas, situadas a lo largo del valle Izabal y del valle Motagua, en combinación con los datos obtenidos del satélite, ha permitido determinar la cinemática y el patrón de estos sistemas. La geometría y la estructura superficial del límite de las placas han sido determinadas a partir de datos geológicos y perfiles sísmicos resultantes de estudios efectuados a lo largo de una línea de $60 \mathrm{~km}$ de longitud al este del Lago Izabal, perpendicular al límite de placas y que interesa el valle Motagua. El Lago Izabal es la mayor cuenca de pull-apart que se ha formado a lo largo del sistema cizallante de Polochic. Los datos obtenidos con el modelo de gravedad confirman las principales características del mapa de anomalías de Bouguer de la zona y explica la mayor parte de las anomalías de amplia longitud de onda, así como aquellas de tipo local asociadas a los cuerpos geológicos de la corteza superficial y sub-superficial. La determinación de la geometría, la profundidad de las cuencas sedimentarias asociadas al sistema cizallante, así como la profundidad de los cuerpos ophiolíticos de la zona de sutura, son los principales resultados derivados de la implementación del estudio geológico y geofísico.
\end{abstract}

Palabras clave: Este de Guatemala, Sistema transformante Polochic-Motagua, modelo gravimétrico, estructura cortical profunda.

\begin{abstract}
Two-dimensional inverse gravity modeling is presented to help determine the deep structural framework of the left-lateral Polochic-Motagua fault systems. They represent a major segment of the North American-Caribbean plate boundary. These seismically active tectonic lineaments, crossing broadly E-W Guatemala, are superimposed over a narrow suture where slices of ophiolitic assemblages crop out. Within the principal displacement zone of the fault systems, pull-apart basins and restraining zones (push-up) were formed. A fault population analysis along the strike of both fault systems in the Izabal and Motagua valleys, combined with satellite-derived data, have allowed determining the gross geometry and kinematics of the transform systems. Geological information and commercial seismic data were used to constrain the shallow geometry and structure of the plate boundary across a 60-km-long cross-section located to the east of Lago Izabal, the largest pull-apart basin formed along the Polochic transform system, and across the Motagua valley. The inverse gravity model fits the complete Bouguer anomaly map of the area and explains most of the observed long-wavelength anomalies, as well as the local anomalies associated with intracrustal and shallow crustal geological bodies. The main features derived from the integrated geophysical-geological approach are the geometry and depth of sedimentary basins associated with the transform systems, and the root of the ophiolitic bodies in the suture zone.
\end{abstract}

Key words: Eastern Guatemala, Polochic-Motagua transform systems, gravity modeling, deep crustal structure. 


\section{Introduction}

The western segment of the North American-Caribbean plate boundary crops out across eastern Guatemala. This boundary is an array of broadly E-W- and ENEWSW-trending lineaments known as the Polochic and Motagua fault systems (Schwartz et al., 1979; Erdlac and Anderson, 1982; Burkart, 1978 and 1983; Beccaluva et al., 1995; Giunta et al., 2002; Giunta et al., 2006, Fig. 1). These left-lateral tectonic lineaments are located, for most of their length, along river valleys bordered by steep mountain chains superimposed to the Motagua suture zone (Dengo and Case, 1990). Ophiolitic bodies crop out along several segments of the faults. The Polochic fault is partially hidden under the 60-km-long, 20-km-wide Lago Izabal, a pull-apart basin developed within the principal displacement zone of the fault system. The Motagua fault to the south lies along a wide river valley running parallel to the Guatemala-Honduras eastern border.

The gross geometry and shallow structure of the
Polochic-Motagua fault systems have been mainly inferred from geological field data and seismic reflection profiles acquired in the eastern part of Guatemala. However, the deep, cross sectional structural framework of this segment of the North American-Caribbean plate boundary remains largely unconstrained. Most of the published gravity crustal models for the Central America region (Bowin, 1976; Case et al., 1990; Mickus, 2003) are concentrated along the offshore part of the plate boundary. A few detailed gravity studies include portions of the Central America mainland, and one was concentrated in western Guatemala (Machorro and Mickus, 1993). Historical earthquakes with moment magnitude larger than 7 have occurred in the last century in this highly populated part of the country. Knowledge of the crustal setting and the seismogenetic zones is of high priority for hazard prevention and preparedness. Gravity measurements may furnish valuable information on lateral changes in mass distribution for crustal-upper mantle models. Gravimetric data may yield correlations between the gravity models and structural instabilities or earthquakes.

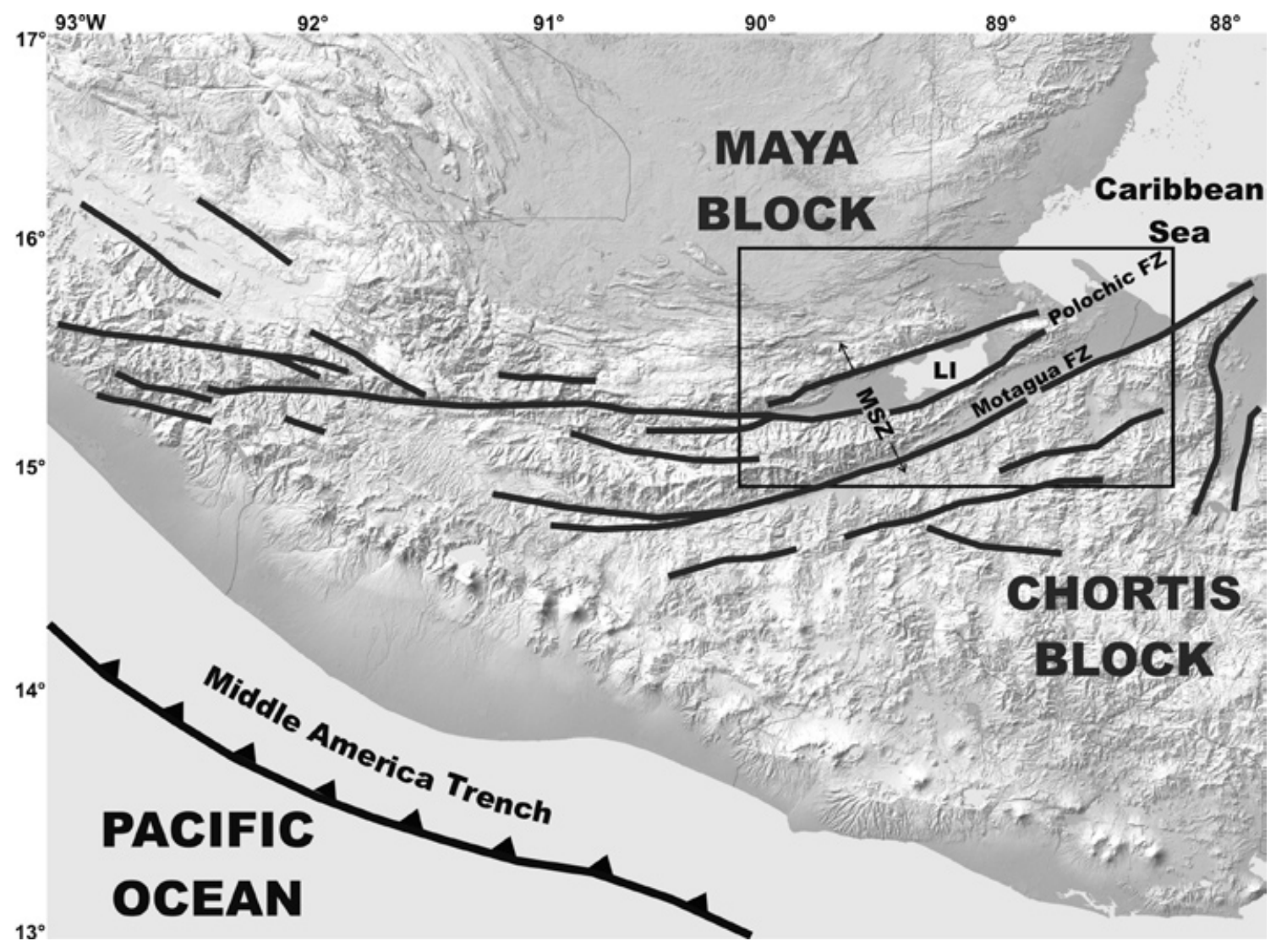

Fig. 1. Simplified morpho-structural map of Guatemala and adjacent regions, with highlighted the main fault segments of the Polochic and Motagua systems. LI: Lago Izabal; MSZ: Motagua suture zone. Frame refers to Figs. 2, 3, 5 and 6. 
In this paper, published and new acquired gravity data are analyzed together with geological information and reflection seismic profiles, to construct a 2-D gravity model of the eastern part of the Polochic-Motagua fault systems. This gravity model is used to map spatial variations in lithosphere thickness, and to infer the deep structure of the transform systems.

\section{Eastern Guatemala regional tectonic setting}

The Polochic-Motagua fault systems run from the Cayman Trough in Caribbean Sea, to the Pacific Ocean, where they terminate against the Middle America Trench. This plate boundary presents clear geomorphologic expression, particularly in the eastern part of Guatemala, as observable from both satellite-derived images and aerial photos, and in the recently unclassified terrain digital elevation models (Shuttle Radar Topographic Mission SRTM - data; Fig. 2). The most important segments of the transform systems in eastern Guatemala are represented, from north to the south, by the North Izabal fault, the Rio Dulce fault, the Polochic fault, the Cabañas fault, and the Motagua fault (Fig. 3). These nearly parallel faults juxtapose the Maya and Chortis continental blocks
(Dengo and Bohenenberger, 1969; Burkart, 1978; Case and Holcombe, 1980; Dengo and Case, 1990; Donnelly et al., 1990), and lie along the Motagua suture zone, an assemblage of ophiolitic complexes highly dismembered and deformed during the Cretaceous-Early Tertiary by a sequence of tectonic events (intraoceanic subduction, arc development, and arc-continent collision), which originated the proto-Caribbean Jurassic-Cretaceous ocean (Beccaluva et al., 1995; Giunta et al., 2006).

The Maya block is located north of the suture zone, and occupies the northern part of Guatemala, the whole Belize and the Yucatan Peninsula. Its basement consists of igneous and metamorphic rocks, overlain by upper Paleozoic, Cretaceous and Cenozoic sedimentary sequences (Burkart, 1994). The Chortis block, located to the south of the suture zone, comprises the entire Honduras and El Salvador, southern Guatemala, and the northern part of Nicaragua (Dengo and Bohnenberger, 1969; Donnelly et al., 1990). Its basement consists of metamorphic rocks of poorly constrained age (ranging from Precambrian to Cenozoic), overlying by Meso-Cenozoic formations mostly composed by volcanoclastic rocks (Gordon, 1991; Lallemant and Gordon, 1999). The Chortis block collided

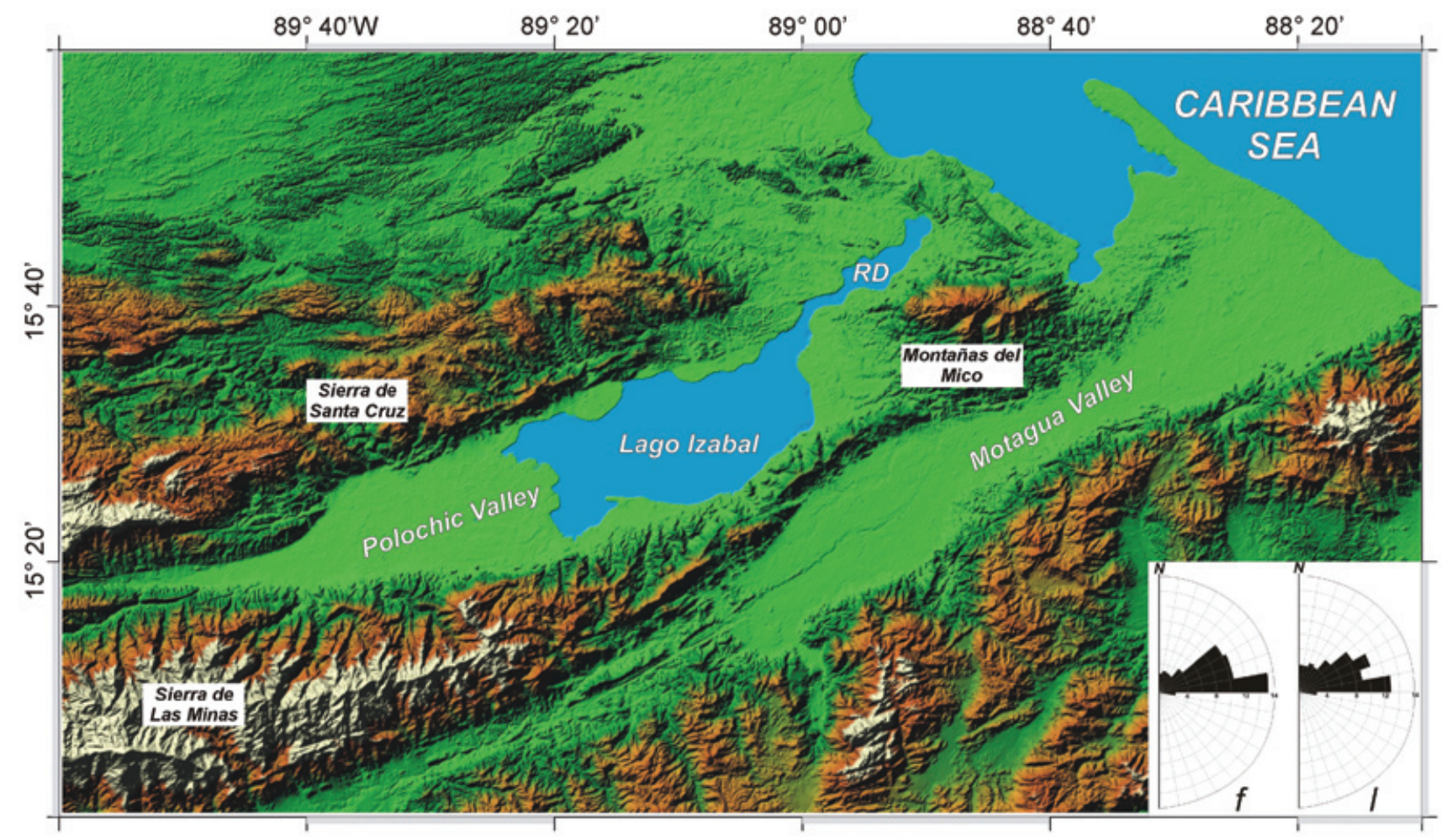

Fig. 2. Shaded-relief Digital Elevation Model of eastern Guatemala obtained from SRTM data. RD: Rio Dulce. On the lower right corner, rose diagrams of the frequency (f) and length (l) of 632 lineaments identified from the analysis of remote-sensing images. 


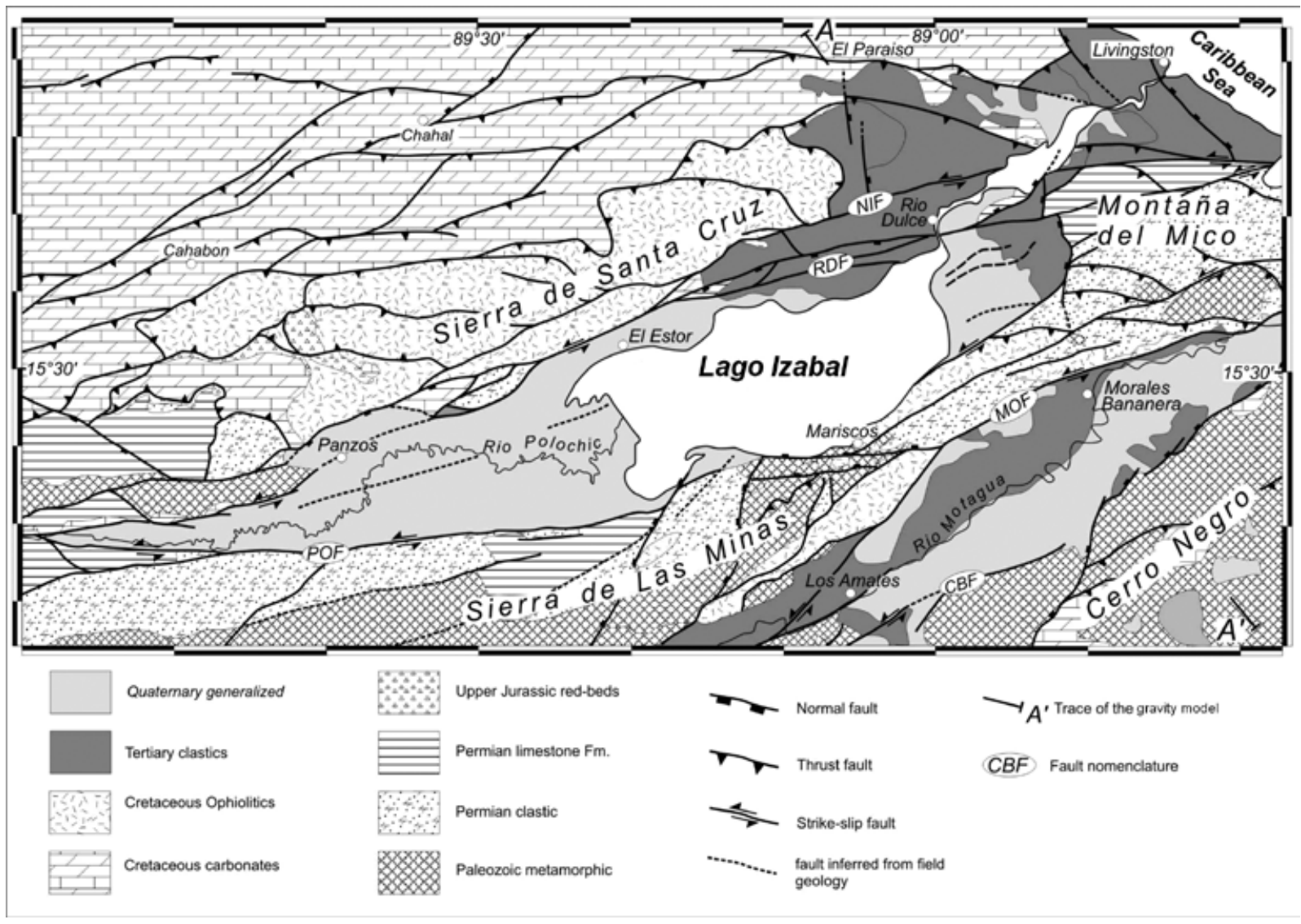

Fig. 3. Geological map of the Izabal area (easternmost Guatemala). Segment A-A' refers to the gravity model presented in Fig. 7. POF: Polochic fault; MOF: Motagua fault; RDF: Rio Dulce fault; NIF: North Izabal fault; CBF: Cabañas fault.

in the Late Cretaceous with the Maya block, producing complex thrust sheets on both the Paleozoic-Mesozoic metamorphic basement and sedimentary covers of the two blocks, often in embricated geometries (Giunta et al., 2002). The suture zone now contains slices of the Maya and Chortis crust together with obducted Late Cretaceous ophiolitic bodies, representing relics of oceanic crust and mantle that once occupied the region between these two continental blocks, as a seaway of the proto-Caribbean oceanic domain (Donnelly et al., 1990; Beccaluva et al., 1995). In the Neogene, left-lateral transcurrent fault zones developed within the suture zone, the most relevant being the Polochic and Motagua tectonic lineaments. The magnitude of the horizontal displacement along these fault is still unconstrained, and different authors report values from tents to hundred of kilometers (Burkart, 1978 and 1983; Schwartz et al., 1979). The stress field along the main faults produced either releasing and restraining zones, the first represented by the Lago Izabal and Motagua depressions, the second by the uplifts of Sierra de la Minas and Montañas del Mico.

\section{Geology of the Izabal area}

The study area is centered on Lago Izabal, the largest lake in Guatemala, and includes also the Sierra de Santa Cruz to the north, the Polochic, Izabal, and Rio Dulce valleys, the Sierra de las Minas, Montañas del Mico, the Motagua valley and Bananera plain, till the GuatemalaHonduras border to the south. The geologic broad aspects are shown in Fig. 3, and are mainly based on the geological map of Guatemala (Bonis et al., 1970), and on the sketch map and cross-sections of Giunta et al. (2002). Ophiolitic units emplaced by thrusting toward N-E, crop out in the Sierra de Santa Cruz. The northern side of the Polochic valley is separated from the Sierra de Santa Cruz by a complex array of en-echelon, left-lateral transtensional fault segments of the Polochic fault. The eastern part of the valley, from Rio Dulce to the Caribbean Sea, is partially closed by the Montañas del Mico, a structural high where several fault segments merge in complex N$\mathrm{NW}$ verging thrust systems involving Paleozoic rocks. The valley developed within the principal displacement zone of the Polochic fault system in rhombo-shaped elongated 
depressions. The western tip of the area coincides with a narrow valley, where many outcrops of the fault plane, with strike-slip character, are located in the triangular facets at the foot of the mountain chain. Small fault segments separate to the south the Polochic valley from the Sierra de las Minas. Here, tectonic slices of serpentinite and peridotites, gabbros and basalts with carbonatic breccia calcarenites, over thrust the Paleozoic metamorphic basement. Far to the N-E, the Sierra de Las Minas merges with the Montañas del Mico, where different splays of strike-slip faults interplay in complex array of the thrust structures. The eastern part of the Motagua valley consists of small and elongated rhombo-shaped basins, the most important being the Bananera plain, approximately $45 \mathrm{~km}$ long and $15 \mathrm{~km}$ wide. The valley is bordered by two fault segments: the Cabañas fault to the south and the Motagua fault to the north. In this valley, the fault traces are hidden by Quaternary alluvium, while to the west the fault exhibits very well geomorphic expression with sag-pods, shudder ridges, scarps, offset streams and river terraces.

The Tertiary to Recent stratigraphic succession of the area surrounding Lago Izabal and the sequences of the basin fill have been mostly reconstructed on the basis of field geological observations, integrated with a large data set of industrial seismic reflection profiles calibrated with the stratigraphy of some wells located both onshore in the vicinity of the lake and offshore in the Caribbean Sea (Weir and Briceño, 1988; Shell, 1993; Cox, 1997). The total thickness of the Tertiary and Quaternary formations is at least $4000 \mathrm{~m}$ in the western part of the Izabal basin, whereas is about $2500-3000 \mathrm{~m}$ in its eastern part. In the Motagua valley, Quaternary fluvial sediments have an estimate thickness of at least $1000 \mathrm{~m}$, but neither seismic nor drilling data are available to derive the total thickness of the Tertiary sedimentary cover.

\section{Field structural analysis and remote-sensing mapping}

The geometry and kinematics of the Polochic and Motagua fault systems were analyzed in several outcrops located along the northern shore of Lago Izabal, in the southern slope of the Sierra de Santa Cruz, and in the Sierra de Las Minas between Lago Izabal and Motagua valley. The features observed in the field consist of scattered slickenside fault surfaces outcropping within the brecciated zone at several localities that commonly record strike-slip movements. The fault segments define an ENE-WSW and an E-W general trend that splits in several splays, and is complicated by jogs, bends and interconnected step-overs. In each locality, the faults were sampled measuring the plane direction, the slip and the sense of movement. In ultramafic rocks as peridotites and basalts, serpentine fibres are used as kinematic indicators for both ductile and brittle deformations. At the outcrop scale, the magnitude of the structures is of the order of meters to tents of meters, because the faults generally have trace lengths of meters to hundreds of meters.

Kinematic fault analyses for the main structural elements associated to the Polochic (POF), North Izabal (NIF), Motagua (MOF), and Cabañas faults (CBF) are presented in Fig. 4. A total of more than 250 faults with shear sense indicators have been analyzed. The Right Dihedra Method (Angelier and Mechler, 1977), capable to determine the likely orientations of principal stress axes via stereographic projection, has been applied. These involve locating on the stereogram the feasible principal stress directions compatible with each fault plane/striation data pair and then, by superimposing stereograms, finding which of these stress directions are common to the different faults measured.

On the S-E slope of the Sierra de Santa Cruz, few shear zones associated with fault planes show a transtensional attitude of the fault striae. The fault plane inclination is about $60^{\circ}$, dipping to S-E. In the southern shore line of Lago Izabal, sub-vertical, N-E dipping sinistral strikeslip faults affect the ophiolitic and the Paleozoic rocks of the Sierra de la Las Minas. This system of faults presents a good geometrical linkage and transfer between the Polochic fault and the system of the northern bank of the Motagua valley. In the south slope of the Montañas del Mico, sub-vertical left-lateral strike-slip planes in the E-W direction shearing different outcrops of Paleozoic rocks. In the Morales-Bananera area, the main surveyed sub-vertical, S-E dipping normal and sinistral strike-slip faults with direction NE-SW, are visible in the ophiolitic rocks of the hanging-wall which belongs to the Cabañas fault. This fault is probably linked westward with subvertical left-lateral strike-slip planes in the E-W direction shearing different outcrops of Paleozoic rocks of the Montaña del Mico. The kinematic analysis shows a subvertical intermediate stress vector $\left(\sigma_{2}\right)$, a sub-horizontal compressional vector $\left(\sigma_{1}\right)$ in the NE-SW direction, and an extensional stress vector $\left(\sigma_{3}\right)$ oriented in a NW-SE direction.

The regional trend of the structures studied in the field has been derived from analyses of remote-sensing maps such as Landsat images, shaded-relief maps produced from SRTM data (3 arc-second resolution; Farr and Kobrick, 2000), and aerial photographs. More than 630 lineaments along the transform systems in eastern Guatemala have been mapped (see the rose diagrams in Fig. 2). Most of the segments, trending from $\mathrm{N} 70^{\circ} \mathrm{E}$ to $\mathrm{N} 90^{\circ} \mathrm{E}$, are concentrated along the valleys where the Polochic and Motagua fault systems strike. There are several geo- 

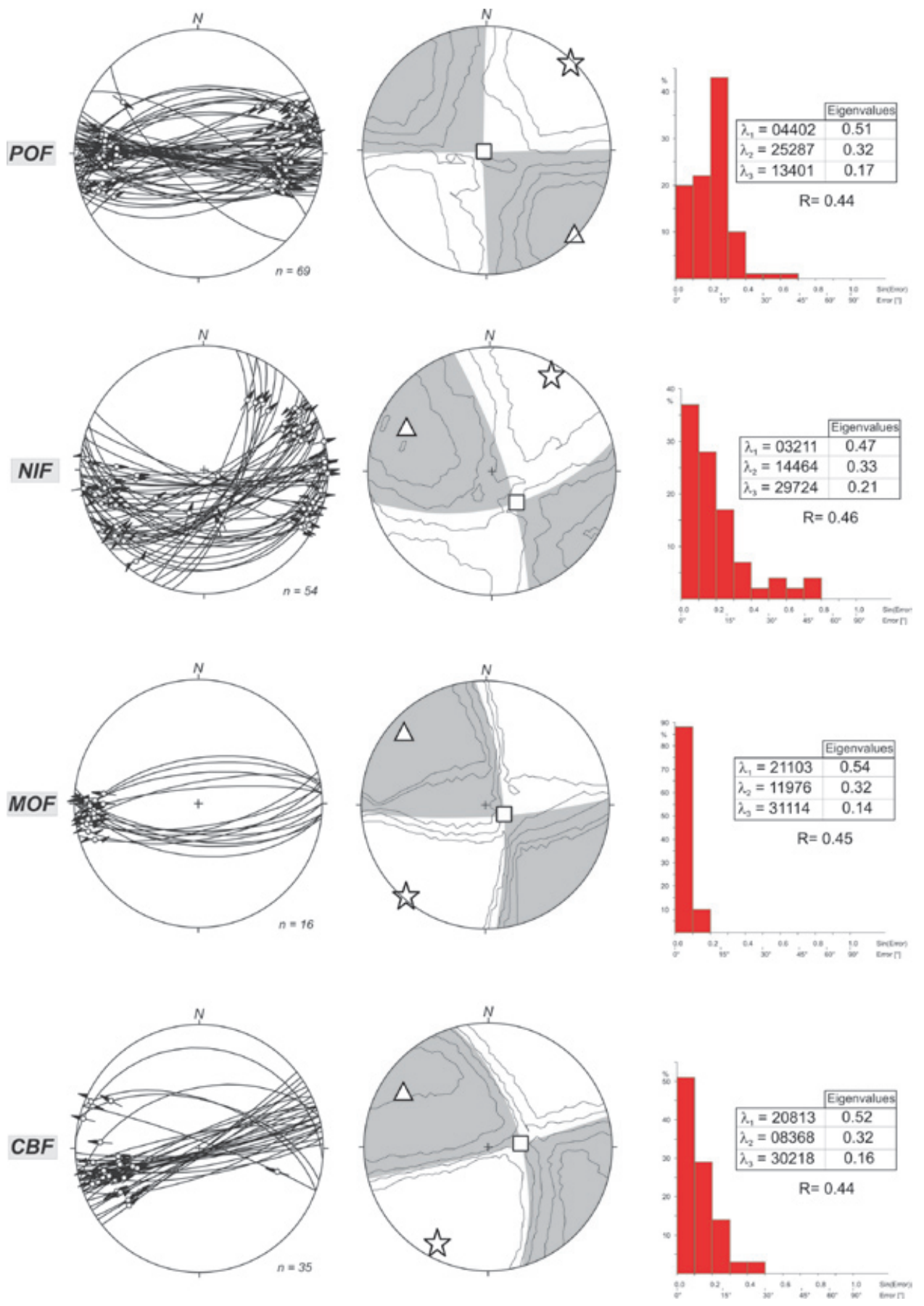

Fig. 4. Kinematic fault analyses for the main structural elements studied in the field, and associated to the Polochic fault (POF), North Izabal fault (NIF), Motagua fault (MOF), and Cabañas fault (CBF). For each structure analyzed, stereograms displayed in the left panel (equal area projection, lower hemisphere) show fault planes and associate slickenlines (arrows point to the direction of hanging wall slip); stereograms displayed in the central panel show kinematic results obtained with the Right Dihedra Method (Angelier and Mechler, 1977 ) with contoured values $(0.01,0.03,0.06,0.09,0.12)$ of the ratio Max/ $\mathrm{N}$, where Max is number of faults considered for calculating the principal direction of shortening, and $\mathrm{N}$ is the total number of faults. Computed stress axes: triangle indicates the extensional axis, square indicates the intermediate axis, star indicates the shortening axis deduced for each fault population. Histograms displayed in the right panel, where dihedral angle between the measured lineation and the stress vector for each fault plane is counted, show the angular misfits between the predicted and actual direction of movement. Ratio $\mathrm{R}=\left(\lambda_{2}-\lambda_{3}\right) /\left(\lambda_{1}-\lambda_{3}\right)$, where $\lambda_{1}, \lambda_{2}$ and $\lambda_{3}$ are eigenvalues of the Bingham moment tensor, has been used to estimate the shape of the stress ellipsoid. 
morphological evidence of present-day activity of the Polochic fault segments in the Lago Izabal area, where the streams flowing from the Sierra de Santa Cruz to the Lago Izabal show a left-lateral offset of many hundreds of meters, possibly related to the fault activity as observed in the far west of Guatemala (Erdlac and Anderson, 1982). Between El Estor and Rio Dulce, several few meters high terraces connect the slope of the Sierra de Santa Cruz with the lake level, while between El Estor and Panzos sharp morphologies with aligned stepped triangular facets bound the northern part of the lake plain. In the lower valley of the Motagua River, Quaternary terraces present offsets of the order of tens of meters.

\section{Gravity data and model}

Gravity measurements used in this study were taken from the Bureau Gravimétrique International (BGI), and the Guatemalan Instituto Nacional de Sismología, Vulcanología, Meteorología e Hidrología (INSIVUMEH).
Most of the data points have been acquired along roads and closer areas, resulting in an average coverage of about one measurement every $2.5 \mathrm{~km}^{2}$. In order to increment the data density along the trace of the deep vertical section to be modeled, and check the data quality, 22 DGPSfixed gravity data points were acquired on February 2003 along a NNW-SSE-trending transect which crosses the Polochic and Motagua valleys (see location in Figs. 3 and 5). The update value of the absolute gravity base used (Puerto Barrios harbor) is given in the International Gravity Standardization Net 1971 (Morelli et al., 1974). Theoretical gravity values were calculated using the geodetic Reference System 1976 gravity formula. The corrected positions are expressed in the WGS-84 system. Instrument drifts and tidal corrections have been applied to the acquired data. The complete Bouguer anomaly map presented in Fig. 5 has been derived using the SRTM elevation data, using a standard density of $2.67 \mathrm{~g} / \mathrm{cm}^{3}$ and a radius of computation of $167 \mathrm{~km}$.

Fig. 5 shows that gravity anomalies range from +15

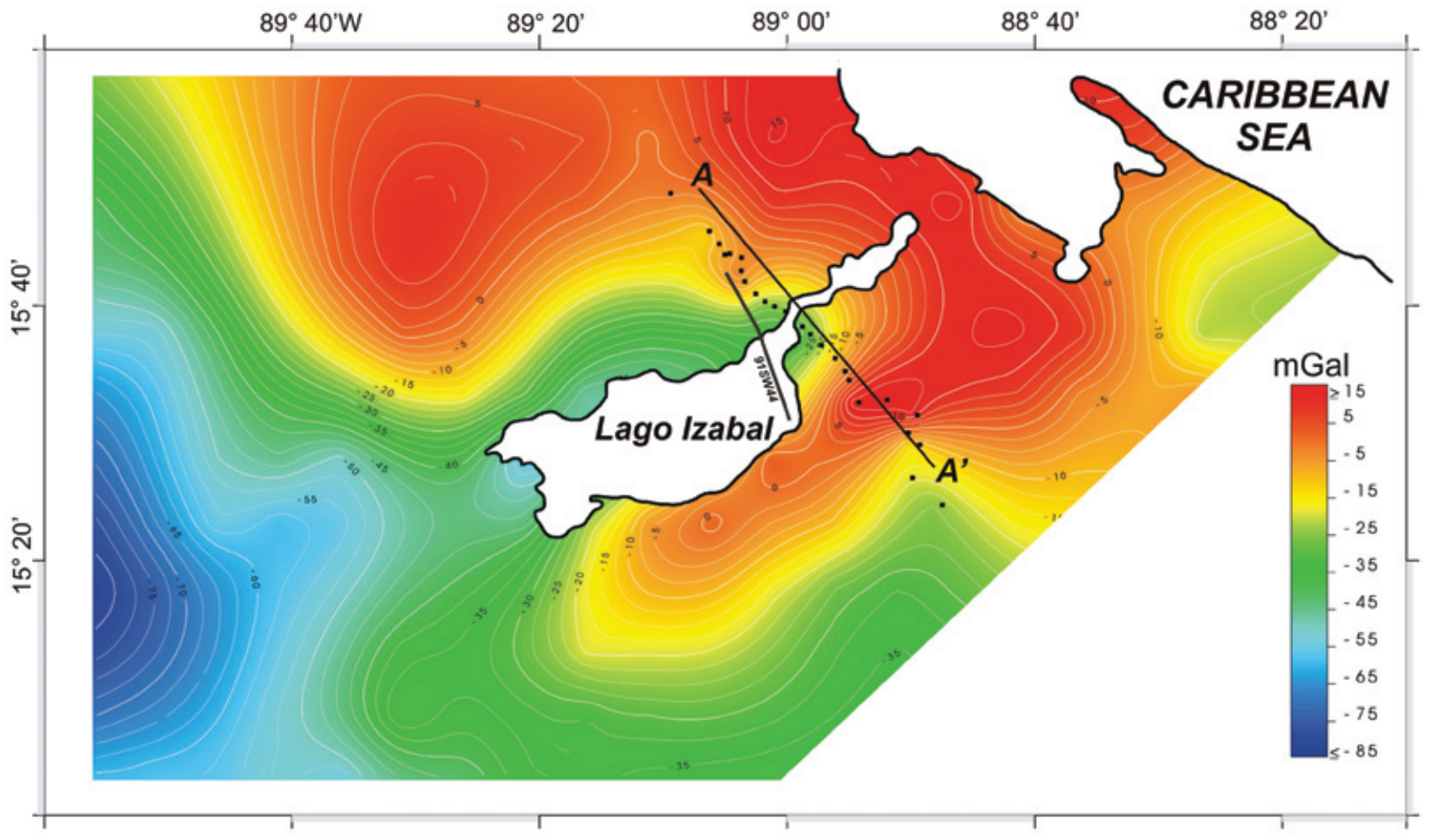

Fig. 5. Complete Bouguer gravity map of the area surrounding Lago Izabal, and location of the cross-sectional gravity model (segment A-A') presented in Fig. 7. Contour interval is $2.5 \mathrm{mGal}$. Small black dots represent the gravity measurements acquired close to the trace of the model presented in Fig. 7. The location of seismic line 91SW44 presented in Fig. 8 is also indicated. 
mGals to -80 mGals. A prominent minimum trends approximately $\mathrm{N} 60^{\circ} \mathrm{E}$ and presents two relative lows: the smaller is centered in correspondence of the N-E part of Lago Izabal $(-55 \mathrm{mGal})$, the broader is located to the west of the Polochic valley and possibly continues further to the west. The Motagua valley does not reflect a significant gravity anomaly minimum, but a trend towards negative values may be recognizable in correspondence of longitude $88^{\circ} 45^{\prime} \mathrm{W}$ and at the eastern termination of the valley towards the Caribbean Sea. Relative gravity maxima are located in the region surrounding Lago Izabal, with the maximum $(+13 \mathrm{mGal})$ in the Montañas del Mico (see the geological map in Fig. 3) where mainly high-density bodies (ophiolitic complexes) are found. Other maxima are located north of Rio Dulce and to the east of the eastern end of Sierra de Santa Cruz where metamorphic rocks crop out. The presence of two principal gravity lows indicates a mass deficit, like a low-density sedimentary body.

In order to isolate more clearly shorter wavelength gravity anomalies arising from shallower geological features which are superimposed on the regional anomaly, a residual gravity anomaly map was obtained (Fig. 6). It has been generated by subtracting from the observed gravity anomaly map, the fourth-order polynomial surface that best fits the regional gravity surface. The residual map enhances the local anomalies obscured by broader regional trends and aid in the definition of the edges of the source bodies. The main features recognizable from Fig. 6 are the shape and extent of the geologic bodies, differentiated by their density contrasts. Two main sedimentary basins are present: one is located in correspondence of the Lago Izabal, with its minimum centered in the vicinity of the northern shore of the lake; the other is located along the Motagua valley and presents a less pronounced gravity minimum. The map clearly displays the edges of high density geologic bodies, which are present in correspondence of the eastern part of Sierra del Las Minas and Montañas del Mico; another high density body is located in the north-western part of the map where ultramafic rocks of the Sierra de Santa Cruz crop out.

To generate a deep crustal model across the PolochicMotagua fault systems, we have utilized the observed gravity anomalies along a NNW-SSE transect (labeled as A-A' in Figs. 3 and 5), located just to the east of Lago Izabal. A classic step-by-step process to derive a plausible cross-sectional body distribution was applied, compatible with the available geological information. A theoretical gravity anomaly is first computed for a two-dimensional

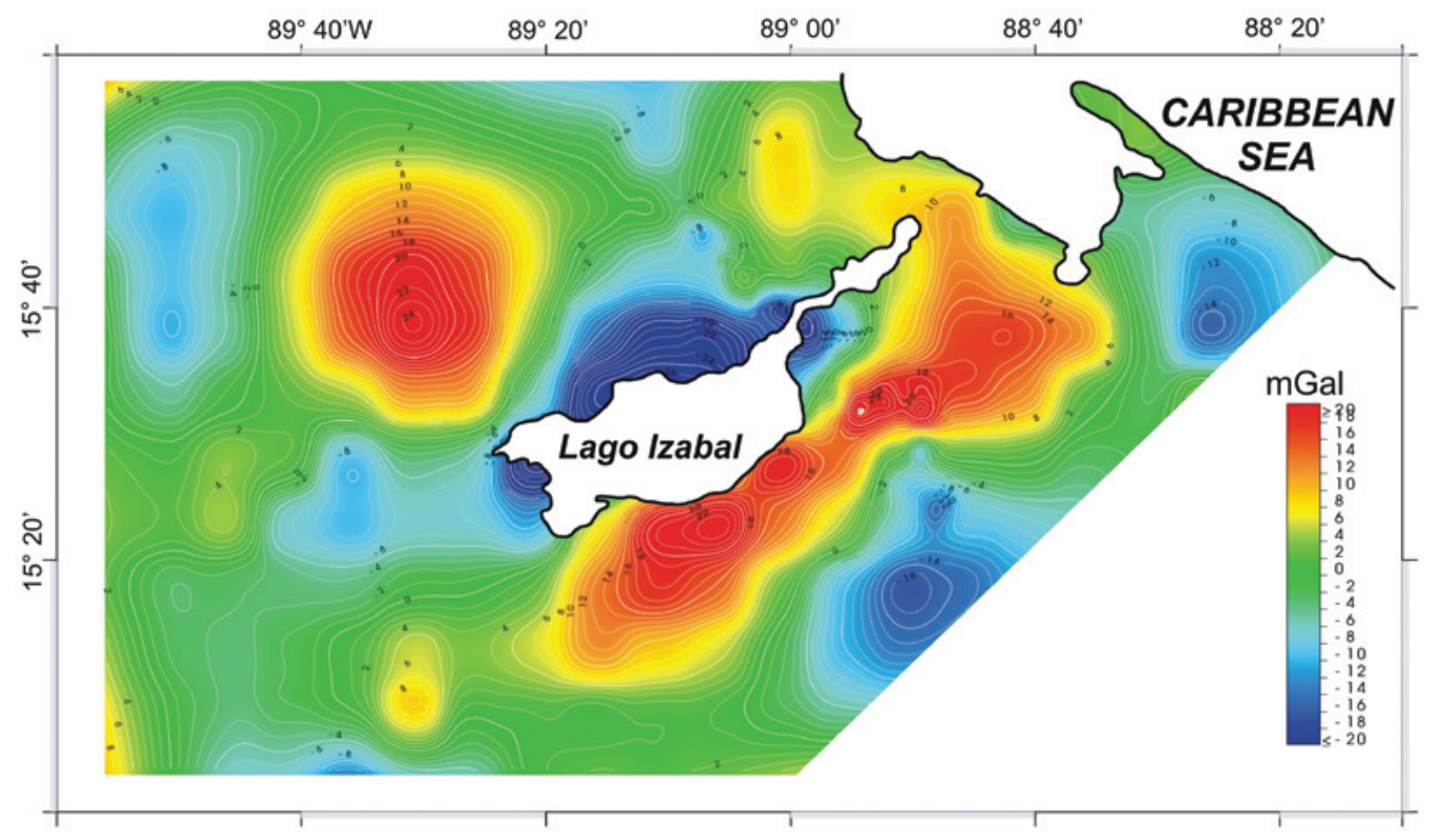

Fig. 6. Residual gravity anomaly map of the area surrounding Lago Izabal. Contour interval is 1 mGal. See text for discussion. 
model, which reproduces subsurface shape, size and position of geological structures, with a density contrast with their surroundings. The computed anomaly is then compared with the observed anomaly, and the shape of the model is altered until the computed anomaly closely matches the observed anomaly. In this method, geological constraints on the nature and form of the anomalous bodies imposed to the model are essential to reduce the intrinsic uncertainty and ambiguity of the inverse problem (e.g., Al-Chalabi, 1971).

The resulting 60-km-long model representing a lithospheric cross-section of the Motagua suture zone and the Polochic-Motagua transform system is shown in Fig. 7. It crosses, from north to the south, the Sierra de Santa Cruz, the Polochic valley, the Montañas del Mico, and the Motagua valley. The geometry and size of the geological features displayed in the gravity model have been imposed by available geological and geophysical information and, in absence of along-section constraints, by extrapolating the field data from the surrounding region. The depth geometry of the sub-vertical Polochic fault and the structure and geometry of the Izabal basin is visible in several multichannel seismic profiles acquired in the last decades by oil companies. A representative seismic line oriented NW-SE and located in the eastern-half of Lago Izabal, is shown in Fig. 8. Data image the geometry and structural framework of this basin, which is highly asymmetric. The observation that the basin asymmetry is toward the transform fault, suggests that subsidence was mostly governed by extension in a direction normal to the regional strike of the transform, at the same time that strike-slip motion is taking place (Ben-Avraham, 1992; Ben-Avraham and Zoback, 1992). For the Motagua valley, where no seismic data are available, we assume a similar geometry in depth. It is necessary to note that the analysis of seismic profiles constrained only the shallower part of the adopted model (up to $4-5 \mathrm{~km}$ in depth), and determined the geometrical shapes and density of the causative sedimentary bodies. The basins associated to the Polochic and Motagua faults present a depth of about $18 \mathrm{~km}$. The choice of the density contrast for these two depressions has been taken considering an average value of $2.5 \mathrm{~g} / \mathrm{cm}^{3}$ for the shallower sedimentary sequences (about $3.5 \mathrm{~km}$ ), as extrapolated from near drilling data, and an average value of $2.55 \mathrm{~g} / \mathrm{cm}^{3}$ for the remaining deeper strata. The depth of the Motagua valley has been assumed similar to the Polochic valley, because the absence of additional

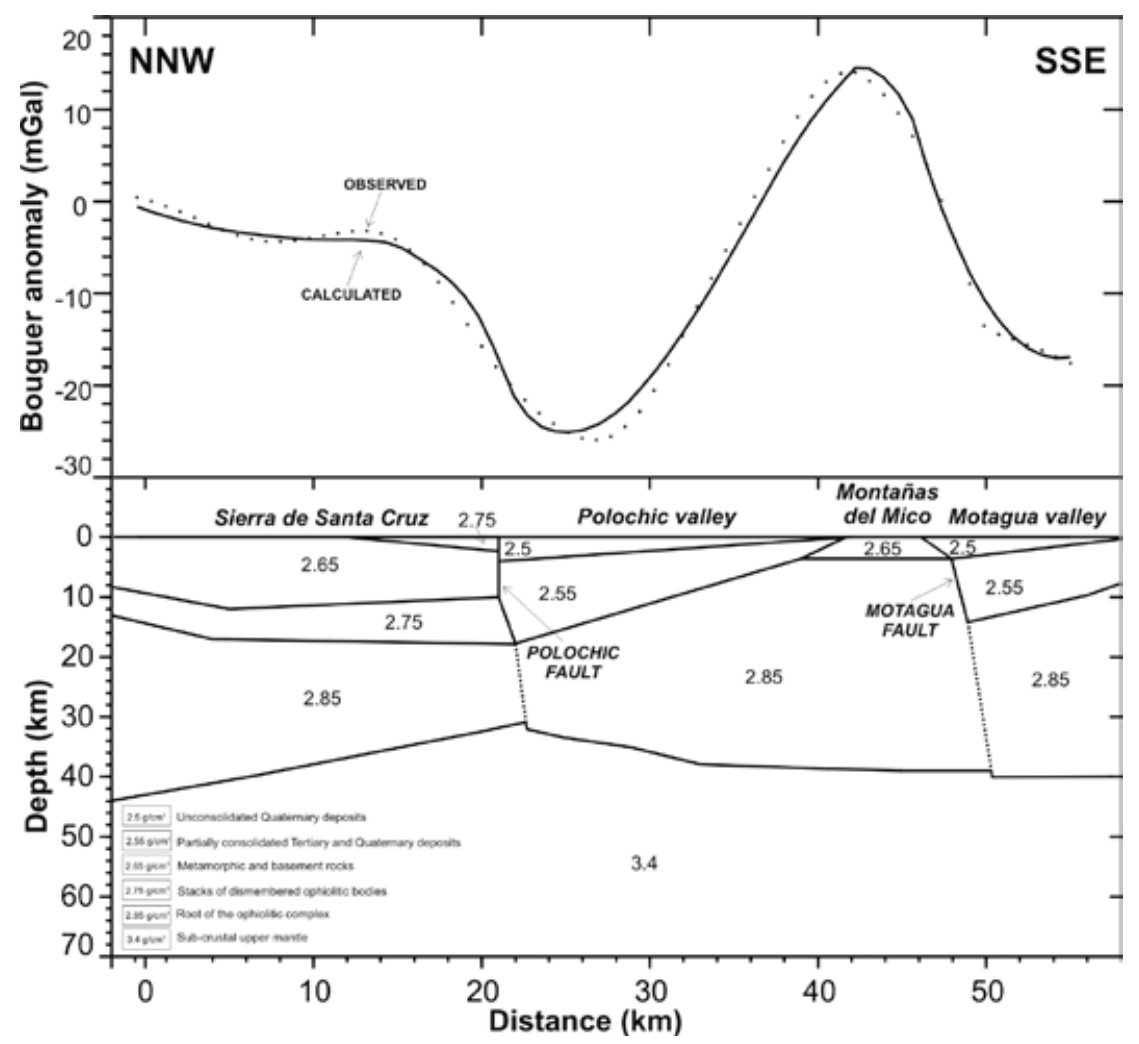

Fig. 7. Two-dimensional gravity crustal model generated by inversion across the Polochic-Motagua transform system (see location in Figs. 3 and 5). Numbers on the geological bodies refer to the applied densities (expressed as $\mathrm{g} / \mathrm{cm}^{3}$ ). On the top of the Figure, the observed and calculated gravity anomalies along the modeled section. The fitting error between the two curves is $1.53 \mathrm{mGal}$. 

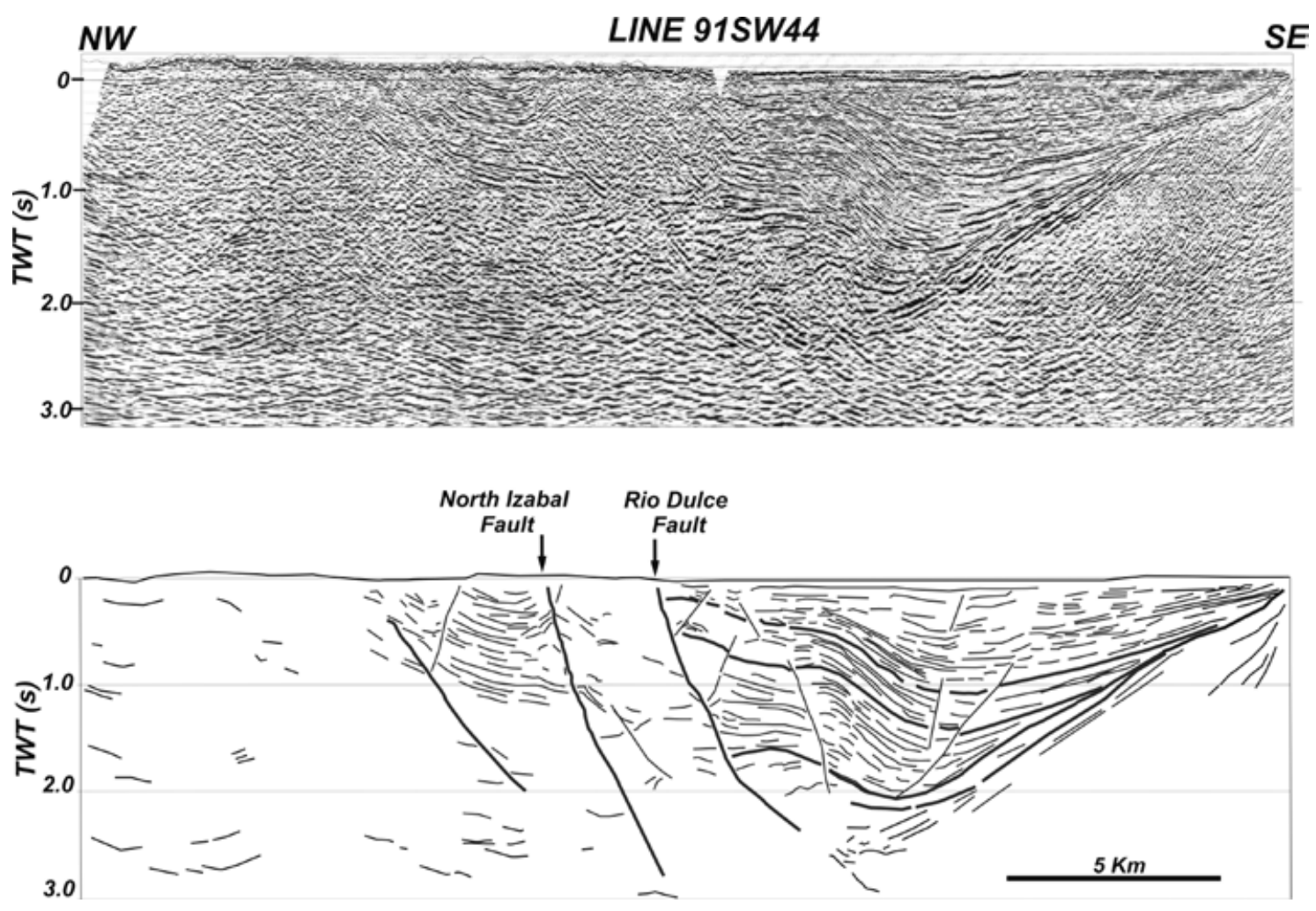

Fig. 8. Multichannel seismic reflection data (top) and line-drawing (bottom) of a profile crossing the central-eastern part of Lago Izabal, and the valley lying to the north (see location in Fig. 5). Data show the presence of a highly asymmetric basin fill, bordered to the north by two sub-vertical faults.

constraints. The Sierra de Santa Cruz and Montañas del Mico metamorphic complexes (average density of $2.65 \mathrm{~g} / \mathrm{cm}^{3}$ ), which were over thrusted by dismembered ophiolitic assemblage (average density of $2.75 \mathrm{~g} / \mathrm{cm}^{3}$ ), represent the high-density causative bodies introduced in the model. The bulk of the ophiolitic root pertaining to the Motagua suture zone has an assigned density of 2.85 $\mathrm{g} / \mathrm{cm}^{3}$. To fit the observed anomalies across the Sierra de Santa Cruz, a slice of a low-density body underneath the metamorphic rocks (density of $2.65 \mathrm{~g} / \mathrm{cm}^{3}$ ) was imposed, taking into account geological considerations. It should be noted that the Sierra de Santa Cruz ophiolitic complex, emplaced to the north since Late Cretaceous on the Maya continental crust and its Mesozoic sedimentary cover, was re-folded and shortened by duplexing in the Paleocene, giving rise to multiple superposition of relatively low density formations, as shown by the gravity signature of the observed data. The top of the sub-continental, high density crustal layer (density of $3.4 \mathrm{~g} / \mathrm{cm}^{3}$ ) beneath the ophiolitic root, lays at about $42-45 \mathrm{~km}$, a depth compatible for a mature continental lithosphere.

\section{Seismicity}

In general, both the Motagua and Polochic faults are seismically active. Large earthquakes are known to have occurred along these faults prior to the onset of instrumental seismology (White, 1984 and 1985; White and Harlow, 1993; Ambraseys and Adams, 1996 and 2001; Montero and Peraldo, 2004). White (1984) reports one earthquake in 1538 and several in the XVIII and XIX century (in 1702, 1713, 1714, 1728, 1733, 1741, 1743, $1750,1765,1785,1786,1795,1798,1816,1817,1820$, and 1821), which range in magnitude from 5.5 to about 7.5. According to available information (White, 1984), the $1538(\mathrm{M}=6.5$ to 7.5$)$ and $1785(\mathrm{M}=7.3$ to 7.5$)$ events took place on the eastern portion of the Polochic fault, within our study area. The 1785 event ruptured some $175 \mathrm{~km}$ of the fault, from western Baja Verapaz to the eastern end of Lago Izabal. Another large earthquake took place on the western side of the Polochic fault in 1816 (M=7.5 to 7.8, White, 1984 and 1985; Montero and Peraldo, 2004). White (1984) suggests that none of the earthquakes in this period took place along the Motagua fault. 
In the period from 1900 to 1963 , there are only a few earthquakes in the study area. Neither Pacheco and Sykes (1992) nor Ambraseys and Adams (1996) report any large, shallow event, while White and Harlow (1993) only report one in 1945. We used the catalog of Engdahl et al. (1998) for earthquakes after 1964. These authors relocated hypocenters originally reported by the International Seismological Centre (ISC) and by the National Earthquake Information Center (NEIC), using refracted, diffracted (PKiKP and PKPdf), and depth phases (pP, pwP, and sP), which greatly improve the accuracy of hypocentral parameters, in particular the depths. Thirteen events were found (Fig. 9), ranging in magnitude from 4.5 to 7.5. Centroid moment-tensor solution for four events in this period (taken from the Harvard Centroid-MomentTensor (CMT) website http://www.globalcmt.org/), have been reported: February $4^{\text {th }}, 1976(\mathrm{Mw}=7.5)$; August, $9^{\text {th }}$, $1980(\mathrm{Mw}=6.5)$; September $2^{\text {nd }}, 1980(\mathrm{Mw}=5.3)$; July $11^{\text {th }}$, $1999(\mathrm{Mw}=6.7)$. All of these events show a substantial component of left-lateral, strike-slip faulting parallel to the trace of the faults described herein and along the offshore continuation of the Río Dulce and North Izabal tectonic segments in the Caribbean Sea (Fig. 9). The most prominent event in eastern Guatemala is the February $4^{\text {th }}$, 1976 earthquake located in the western Motagua valley (e.g., Plafker, 1976; Kanamori and Stewart, 1978) whose $230 \mathrm{~km}$-long rupture along the Motagua fault initiated at latitude $15.3 \mathrm{~N}$ and longitude 89.1 W (see Fig. 9) and propagated westward. Here, co-seismic superficial ruptures with offset of more than $1 \mathrm{~m}$ have been estimated (Kanamori and Stewart, 1978).

However, seismic activity in eastern Guatemala is not restricted to the trace of the Motagua and Polochic faults. Events south of these segments (see Fig. 9) may be related to activity along the grabens of the northern Central America (Guzmán-Speziale, 2001). On the other hand, some events are located north of the Polochic fault. White (1984) noticed that most of the seismic activity in Guatemala in the XVIII century occurred on faults up to $80 \mathrm{~km}$ north of the Polochic fault.

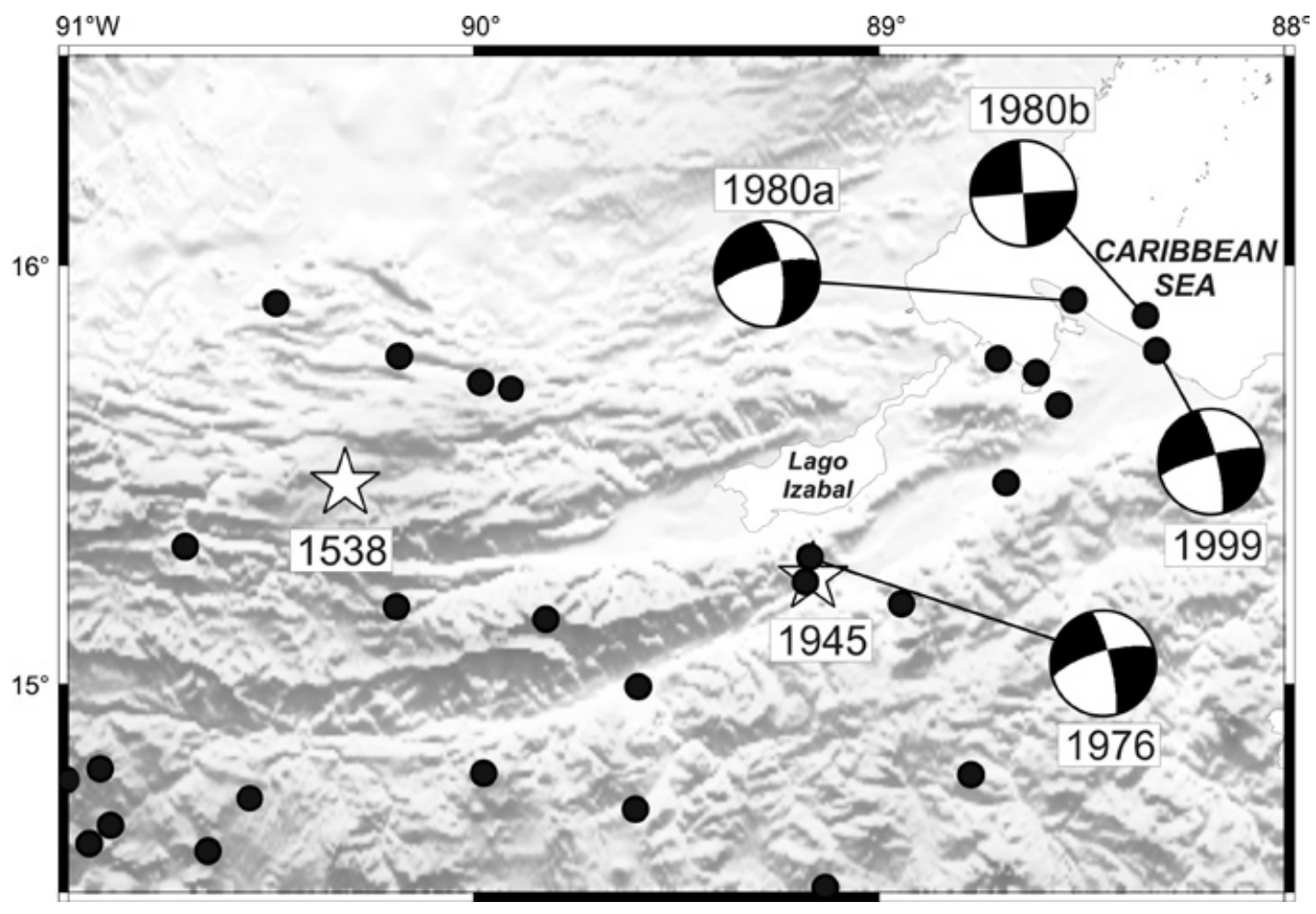

Fig. 9. Shallow seismicity of eastern Guatemala and adjacent countries. Best located epicenters for shallow events in the period 19642005 are shown with black circles. Stars represent the approximate location of the 1538 and 1945 events. Fault-plane solutions of four events are also shown (from Harvard Centroid-Moment-Tensor (CMT) Project website http://www.globalcmt.org/). See text for further details. 


\section{Discussion}

Guatemala is located in a complex tectonic setting influenced by the interaction of three tectonic plates: the North American plate to the north, the Caribbean plate to the south, and the Cocos plate to the south-west. Most of the earthquakes are located off the Pacific coast of Guatemala along the Middle America Trench, where the oceanic Cocos plate is subducting underneath the westernmost Caribbean plate. However, destructive historical earthquakes, with moment magnitude greater than 7 , have occurred in the last century also in the central and eastern part of Guatemala (see Fig. 9). Several morphological features possibly associated with coseismic deformations along shear zones are well exposed on both the Izabal and Motagua valleys and along their flanks, as seen on both remote-sensing images and in the field. Offset of streams of about $1 \mathrm{~km}$ in the northern shore of Lago Izabal shows Quaternary activity of the fault segments. The terrace offsets in the lower valley of the Motagua River in western Guatemala show a slip of 1.5 to $6 \mathrm{~mm} / \mathrm{yr}$ for the last $10 \mathrm{ka}$ to $40 \mathrm{ka}$ and less than $11 \mathrm{~mm} / \mathrm{yr}$ in the last century (Schwartz et al., 1979; Schwartz, 1985).

The bulk displacement along the North AmericanCaribbean plate boundary, calculated on the basis of spreading rates in the Cayman Trough, is more than $1000 \mathrm{~km}$ (Rosencrantz et al., 1988), with an average displacement rate of about $20 \mathrm{~mm} / \mathrm{yr}$ over the last $10 \mathrm{Ma}$. This total horizontal offset is partitioned along the different segments comprising the 500-km-long Polochic-Motagua transform systems. In western Guatemala, Cenozoic stratigraphic controls on both sides of the Polochic fault suggest that the offset was about $130 \mathrm{~km}$ since $10.3 \mathrm{Ma}$, corresponding to a slip rate of $13 \mathrm{~mm} / \mathrm{yr}$ (Burkart, 1978; Deaton and Burkart, 1984). The vicinity of the rotation pole for the North American-Caribbean curvilinear plate boundary produces different resulting strain vectors along the partitioned segments of the Motagua suture zone, with prevailing restraining bend structures in western Guatemala and releasing bend structures in eastern Guatemala. Obviously, the movement of the Maya and Chortis blocks is more complicated than the simple oblique convergence of rigid blocks. In the Maya block, the strain is partitioned in several compressional fault jogs (Guzmán-Speziale and Meneses-Rocha, 2000), while the movements of the Chortis block could be not described in terms of simple rotations but it is necessary to consider several smaller blocks which adjust the whole kinematic of the plate (Burkart and Self, 1985; Gordon and Muehlberger, 1994). Recent field surveys (Gordon and Muehlberger, 1994) and regional tectonic reconstructions (Ross and Scotese, 1988; Pindell, 1994; Meschede and
Frisch, 1988; Giunta et al., 2002), do not show any N-S compressional field strain in eastern Guatemala, testifying that significant compressional-related structures (Sierra del Las Minas and Montañas del Mico) may form in a transtensional tectonic scenario. The presence of these positive structures in a mainly extensional strike-slip regime is well displayed in analogue models and do not require necessarily a change in the stress regime from transtension to transpression (Dooley and McClay, 1997; Reijs and McClay, 2003). GPS-based geodetic measurements confirm the transtension field in eastern Guatemala, and show that the present-day westward slip of the Maya block is of $18.5 \mathrm{~mm} / \mathrm{yr}$, with an extensional component of $4.8 \mathrm{~mm} / \mathrm{yr}$ (DeMets et al., 2000; Mann et al., 2002).

The analysis of the strain vectors as determined from GPS-based data represent an important source of information to identify the areas most suitable to accumulate stress and hence suitable for subtle energy releases, like the tectonic faults during the occurrence of an earthquake. The gravity model here presented, which crosses the seismogenetic Polochic-Motagua transform systems, images with an acceptable confidence the geometry of the basin formed within the Polochic and Motagua principal displacement zones, the spatial relationships between the involved portions of continental crust, and the position in depth of the ophiolitic root that constitute a significant part of the Motagua suture zone. The analysis of the seismicity of the region, allows to better constrain the model, through knowledge of the rock velocities and the elastic property distributions with depth.

\section{Conclusions}

We have constructed a two-dimensional crustal section across the Polochic-Motagua transform systems, a major segment of the North American-Caribbean plate boundary, through inversion of gravity data. The shallow constraints on the geometry, size, and nature of the causative bodies, have been imposed considering available geological information, seismic reflection profiles, and field reconnaissance performed along the most important outcrops of the fault segments. A fault population analysis conducted in several sites has allowed determining the gross geometry and kinematics of the transform systems. The fault segments define an ENEWSW and an E-W general trend that splits in several splays. The sense of movement is mostly sinistral, with an extensional horizontal component. These active, strikeslip faults traverse broadly E-W the entire Guatemala, and have generated for most of their length peculiar narrow and elongated valleys, asymmetric pull-apart basins, and restraining linear uplifts. Destructive earthquakes have 
occurred in recent times along the strike of the transform systems, and several co-seismic morphological features have been found both in the field and from analysis of remote-sensing images.

The obtained crustal model images with an acceptable confidence the position in depth of the ophiolitic root, which constitute a significant part of the Motagua suture zone, and the geometry of the basin formed within the Polochic and Motagua principal displacement zones. The integration of the deep structural framework of the active transform systems generated by inversion of geophysical data, with the analysis of the seismic events in terms of mechanism of motion, represents one of the fundamental approaches for studying seismogenetic lineaments, and for planning a rigorous and effective seismic hazard assessment.

\section{Acknowledgements}

The authors wish to thank Francisco Ordoñez (Ministerio de Energía y Minas de Guatemala) for gently providing the seismic profile used in this study.

\section{Bibliography}

Aguilera, J. G., 1920. The Sonora earthquake of 1887 , Bull. Seism. Soc. Am. 10, 5-56.

Aki, K. and B. Chouet, 1975. Origin of coda waves: source, attenuation and scattering effects, J. Geophys. Res. 80, 3322-3342.

Al-Chalabi, M., 1971. Some studies relating to nonuniqueness in gravity and magnetic inverse problems. Geophysics, 36, 835-855.

Ambraseys, N. N. and R. D. Adams, 2001. The Seismicity of Central America: A Descriptive Catalogue, 18981995, World Scientific Publishing Co., 309 pp.

Ambraseys, N. N. and R. D. Adams, 1996. Largemagnitude Central American earthquakes, 1898-1994. Geophys. J. Int., 127 (3), 665-692 doi:10.1111/j.1365246X.1996.tb04046.x.

Angelier, J. and P. Mechler, 1977. Sur une méthode graphique de recherche des contraintes principales également utilisable en tectonique et en séismologie: la méthode des dièdres droits. Bull. Soc. Géol. France, (7), XIX, 6, 1309-1318.

Beccaluva L., S. Bellia, M. Coltorti, G. Dengo, G. Giunta, J. Mendez, J. Romero, S. Rotolo and F. Siena, 1995. The north-western border of the Caribbean Plate in
Guatemala: new geological and petrological data on the Motagua ophiolitic belt. Ofioliti, 20, (1), 1-15.

Ben-Avraham, Z., 1992. Development of asymmetric basins along continental transform faults. Tectonophysics, 215, 209-220.

Ben-Avraham, Z. and M. D. Zoback, 1992. Transformnormal extension and asymmetric basins: An alternative to pull-apart models, Geology, 20, 423426.

Bonis, S., O. H. Bohnenberger and G. Dengo, (compilers), 1970. Mapa geológico de la República de Guatemala. Instituto Geográfico Nacional. Scale 1:500,000.

Bowin, C., 1976. Caribbean gravity field and plate tectonics. Geol. Soc. Am. Spec. Pub., 169, 79 pp.

Burkart, B., 1978. Offset across the Polochic fault of Guatemala and Chiapas, Mexico. Geology, 6, 328332.

Burkart, B., 1983. Neogene North-American-Caribbean plate boundary across northern Central America: offset along the Polochic fault. Tectonophysics, 99, 251-270.

Burkart, B., 1994. Northern Central America. In: S.K. Donovan and T.A. Jackson (editors), Caribbean Geology: An Introduction. Univ. West Indies Publ. Assoc., Kingston, Jamaica, 265-284.

Burkart, B. and S. Self, 1985. Extension and rotation of crustal blocks in northern Central America and effect on the volcanic arc. Geology, 13, 22-26.

Case, J. H. and T. L. Holcombe, 1980. Geologic-tectonic map of the Caribbean. Scale 1:2.500.000. U.S. Geol. Surv. Miscell. Invest. Ser. Map I/1100.

Case, J. H., W. D. MacDonald and P. J. FOX, 1990. Caribbean crustal provinces: Seismic and gravity evidence. In: G. Dengo and J. E. Case (editors), The Caribbean region, The Geology of North America, vol. H., Geol. Soc. Am., 15-36.

Cox, K. S., 1997. A multi-channel seismic approach to the kinematic evolution of the Lake Izabal basin, Guatemala. Unpublished MSc Thesis, University of Texas at Arlington, $212 \mathrm{pp}$.

Deaton, B. C. and B. Burkart, 1984. Time of sinistral slip along the Polochic fault of Guatemala. Tectonophysics, 102, 297-313. 
DeMets, C., P. Jansma, G. Mattioli, T. Dixon, F. Farina, R. Bilham, E. Calais and P. Mann, 2000. GPS geodetic constraints on Caribbean-North America plate motion. Geophys. Res. Lett., 27, 437-440.

Dengo G. and O. Bohnenberger, 1969. Structural development of northern Central America. Am. Ass. Petr. Geol. Mem., 11, 203-220.

Dengo, G. and J. E. Case, 1990. The Geology of North America, Volume H. The Caribbean Region. Geol. Soc. Am., 528 pp.

Donnelly, T. W. G. S. Horne, R. C. Finch and E. Lopez Ramos, 1990. Northern Central America; the Maya and Chortis blocks. In: G. Dengo and J.E. Case (editors), The Caribbean region, The Geology of North America, vol. H., Geol. Soc. Am., 37-76.

Dooley, T. and K. McClay, 1997. Analogue modelling of pull-apart basin. Am. Ass. Pet. Geologist, 81, 18041826.

Dziewonski, A. M and J. H. Woodhouse, 1983. An experiment in systematic study of global seismicity: centroid-moment tensor solutions for 201moderate and large earthquakes of 1981. J. Geophys. Res., 88, 3247-3271.

Engdahl, E. R., R. van der Hilst and R. Buland, 1998. Global teleseismic earthquake relocation with improved travel times and procedures for depth determination. Bull. Seism. Soc. Am., 88, 722-743.

Erdlac, R. J. and T. H. Anderson, 1982. The ChixoyPolochic fault and its associated fractures in western Guatemala. Geol. Soc. Am. Bull., 93, 57-67.

Farr, T. G. and M. Kobrick, 2000. Shuttle Radar Topography Mission produces a wealth of data. Eos Transactions, Am. Geophys. Union, 81, 583-585.

Giunta G., L. Beccaluva, M. Coltorti, D. Cutrupia, C. Dengo, G. Harlow, B. Mota, E. Padoa, J. Rosenfeld and F. Siena, 2002. The Motagua Suture Zone in Guatemala, Field Trip Guide Book of the I.G.C.P. 433 Workshop and 2nd Italian-Latin American Geological Meeting in memory of Gabriel Dengo. Ofioliti, 27, (1), 47-72.

Giunta G., L. Beccaluva and F. Siena, 2006. Caribbean Plate margin evolution: constraints and current problems. Geologica Acta, Vol. 4, No1-2, 265-277.
Gordon, M. and W. R. Muehlberger, 1994. Rotation of the Chortis block causes dextral slip on Guayape fault. Tectonics, 13, 858-872.

Gordon, D. M., 1991. The Chortis Block is a continental, pre-Mesozoic terrane. In: D. K. Larue and G. Draper (editors), Transaction of the 12th Caribbean Geological Conference, St Croix, U.S. Virgin Island, Miami Geol. Soc., 505-512.

Guzmán-Speziale, M., 2001. Active seismic deformation in the grabens of northern Central America and its relationship to the relative motion of the North America-Caribbean plate boundary. Tectonophysics, 337, 39-51.

Guzmán-Speziale, M. and J. J. Meneses-Rocha, 2000. The North America-Caribbean plate boundary west of the Motagua-Polochic fault system: a fault jog in Southeastern Mexico. J. South Am. Earth Science, 13, 459-468.

Kanamori, H. and G. Stewart, 1978. Seismological aspects of the Guatemala earthquake of February 4, 1976. J. Geophys. Res., 83, 3427-3434.

Lallemant, H. G. and M. B. Gordon, 1999. Deformation History of Roatàn Island: implications for the origin of the Tela Basin (Honduras). In P. Mann (editor), Caribbean basins. Sedimentary basin of the World, Elsevier Amsterdam, Series 4, 197-218.

Machorro, R. and K. L. Mickus, 1993. Structural continuity of the Polochic fault into SW Mexico. EOS Transactions, Am. Geophys. Union, 74, 576.

Mann, P., E. Calais, J.-C. Ruegg, C. DeMets, P. E. Jansma and G. S. Mattioli, 2002. Oblique collision in the northeastern Caribbean from GPS measurements and geological observations. Tectonics, 21(6), 1057, doi:10.1029/2001TC001304.

Meschede, M. and W. Frisch, 1998. A plate tectonic model for the Mesozoic and Early Cenozoic history of the Caribbean plate. Tectonophysics, 296, 69-291.

Mickus, K., 2003. Gravity constraints on the crustal structure of Central America. In: C. Bartolini, R.T. Buffler and J. Blickwede (editors), The Circum-Gulf of Mexico and the Caribbean: Hidrocarbon habitats, basin formation, and plate tectonics. Am. Ass. Petr. Geol. Memoir, 79, 638-655. 
Montero, W. and G. Peraldo, 2004. Current knowledge on the Central America historical seismicity: an analysis of recent catalogues. Annals of Geophys., 47, 477485.

Morelli, C., C. GantaR, T. Honkasalo, R.K. McConnell, I.G. Tanner, B. Szabo, U. Uotila and Whalen, C.T. 1974. The International Gravity Standardization Net 1971, I.U.G.G. Int. Ass. Geodesy Spec. Pub., 4, 194 pp.

Pacheco, J. F. and L. R. Sykes, 1992. Seismic moment catalog of large, shallow earthquakes, 1900-1989. Bull. Seism. Soc. Am., 82, 1306-1349.

Pindell, J. L., 1994. Evolution of the Gulf of Mexico and the Caribbean. In: S.K. Donovan and T.A. Jackson (editors), Caribbean Geology: An Introduction. Univ. West Indies Publ. Assoc., Kingston, Jamaica, 13-39.

Plafker, G., 1976. Tectonic aspects of the Guatemalan earthquake of 4 February 1976. Science, 193, 12011208.

Reijs J. and K. McClay, 2003. The Salina del Fraile pullapart basin northwest Argentina. In: F. Storti, R.E. Holdsworth and F. Salvini (editors), Intraplate strikeslip deformation belts. Geol. Soc. London, Spec. Pub., v. 210, 197-209.

Rosencrantz, E. et al., 1988. Age and spreading history of the Cayman Trough as determined from depth, heat flow, and magnetic anomalies. J. Geophys. Res., 21412157.

Ross, M. I. and C. R. Scotese, 1988. A hierarchical tectonic model of the Gulf of Mexico and Caribbean region. Tectonophysics, 155, 139-168.

Schwartz, D. P., 1985. The Caribbean-North America plate boundary in central America: New data on Quaternary tectonics. Earthquake Notes, 55, 28 pp.

Schwartz, D. P., L. S. Cluff and T. W. Donnelly, 1979. Quaternary faulting along the Caribbean-North American plate boundary in Central America. Tectonophysics, 52, 431-445.

Shell Exploradora y Productora de Guatemala, 1993. Informe Final de Exploracíon. Guatemala City. Unpub. Rep.

Weir, G. M. and N. Briceño, 1988. Potencial petrolero de la cuenca del Lago de Izabal, Guatemala, EP 90-2734 (AMOCO).
White, R. A., 1985. The Guatemala earthquake of 1816 on the Chixoy-Polochic fault. Bull. Seism. Soc. Am., 75, 455-473.

White, R. A., 1984. Catalog of historic seismicity in the vicinity of the Chixoy-Polochic and Motagua faults, Guatemala. U. S. Geol. Surv. Open-File Rep. 84-88, $34 \mathrm{pp}$.

White, R. A. and D. H. Harlow, 1993. Destructive uppercrustal earthquakes in Central America since 1900. Bull. Seism. Soc. Am., 83, 1115-1142. 